\title{
Nutrisi dan Organoleptik Non-Flaky Crackers dengan Penambahan Berbagai Bahan Pangan Alami Kaya Serat Pangan
}

\section{Nutritional and Organoleptic Quality of Non-Flaky Crackers with an Addition of Various Dietary Fiber-Rich Natural Food Ingredients}

\section{Yovie F. Santoso* , Fransiscus S. Pranata, Yuliana R. Swasti}

\author{
Jurusan Biologi, Fakultas Teknobiologi, Universitas Atma Jaya Yogyakarta, Jl. Babarsari 44, \\ Kampus II Gedung Thomas Aquinas, Yogyakarta 55281
}

*Penulis untuk Korespondensi: Yovie F. Santoso, e-mail: santosoyovie@gmail.com

Tanggal submisi: 29 September 2020; Tanggal penerimaan: 12 Maret 2021

\begin{abstract}
Dietary fibre is a food component, which has an important role in human health. Dietary fiber consumption promotes cardiovascular health, weight management, and other benefits. Indonesia has an abundance of natural food ingredients, making it easy to meet human dietary fiber requirements. Non-flaky crackers are a bakery product such as snacks with no layers inside and have a neutral or slightly sweet and salty favour. Some natural ingredients added to non-flaky crackers are green bean, microalgae, citrus seeds, broccoli co-products, Hibiscus sabdariffa residue and blackcurrant pomace. The addition of natural ingredients can increase the nutrition and organoleptic quality of nonflaky crackers.
\end{abstract}

Keywords: Dietary fibre; natural ingredients; non-flaky crackers; nutrition content; organoleptic

(c) The Authors. Publisher Universitas Pattimura. Open access under CC-BY-SA license.

\begin{abstract}
ABSTRAK
Serat pangan merupakan komponen pada makanan yang memiliki peran penting bagi kesehatan manusia. Konsumsi serat pangan dapat membantu meregulasi kesehatan kardiovaskular, menyeimbangkan berat badan dan kesehatan lainnya. Indonesia memiliki keberagaman bahan pangan alami yang berlimpah, oleh karena itu mudah untuk memenuhi kebutuhan serat pangan bagi manusia. Non-flaky crackers adalah produk bakery berupa snack, yang tidak memiliki lapisan di dalamnya dan memiliki rasa netral, atau sedikit manis dan asin. Beberapa bahan yang dapat ditambahkan pada non-flaky crackers untuk meningkatkan kadar serat diantaranya adalah kacang polong, mikroalga, biji jeruk, brokoli co-products, Hibiscus sabdariffa residue dan blackcurrant pomace. Penambahan bahan pangan alami tersebut meningkatkan kualitas nutrisi dan organoleptik non-flaky crackers.
\end{abstract}

Kata kunci: Bahan alami; kadar nutrisi; non-flaky crackers, organoleptik; serat pangan

(C) Penulis. Penerbit Universitas Pattimura. Akses terbuka dengan lisensi CC-BY-SA.

\section{PENDAHULUAN}

Kualitas merupakan hal yang penting dalam suatu produk bagi konsumen. Kualitas produk yang baik menyebabkan tingginya kepuasan konsumen terhadap produk (Lasander, 2013). Selain kepuasan konsumen, kualitas juga diperlukan bagi produk makanan agar aman jika dikonsumsi oleh konsumen. Kualitas makanan yang baik di Indonesia diatur dalam Standar Nasional Indonesia (SNI). Syarat mutu yang ditentukan dalam Standar Nasional Indonesia untuk produk makanan meliputi keriteria berupa keadaan fisik, kadar air, protein, asam lemak bebas, cemaran logam dan cemaran mikroba (Badan Standarisasi Nasional, 2011).

Kualitas makanan yang baik tentunya memiliki kandungan nilai gizi yang baik agar dapat memenuhi gizi seimbang, sehingga memberikan manfaat baik bagi kesehatan tubuh manusia. Peningkatan kualitas juga dapat dilakukan dengan 
menambahkan kandungan serat pangan dalam suatu produk makanan, karena serat pangan memiliki peran penting bagi kesehatan manusia. Konsumsi serat pangan dapat memberikan manfaat berupa membantu kesehatan pencernaan manusia, membantu meregulasi kesehatan kardiovaskular, menyeimbangkan berat badan dan kesehatan lainnya (López-Marcos et al., 2015). Pemenuhan kebutuhan serat pangan dapat dilakukan dengan mengonsumsi bahan pangan yang berasal dari tumbuh-tumbuhan karena serat pangan termasuk polimer karbohidrat dari tumbuhan (Yilmaz dan Karaman, 2019).

Indonesia memiliki keberagaman bahan pangan alami yang melimpah, sehingga mudah untuk memenuhi kebutuhan serat pangan. Serat pangan banyak ditemukan di dalam bahan pangan yang berasal dari tumbuhan berupa serealia, sayursayuran, buah-buahan dan kacang-kacangan (Cui et al., 2019); atau sisa dari produksi bahan pangan berupa limbah (residu) dan produk sampingan (byproduct) (Isik dan Topkaya, 2016). Contoh bahan pangan yang memiliki kandungan serat pangan adalah kacang polong (Millar et al., 2017), mikroalga (Batista et al., 2019), contoh serat pangan berasal dari produk samping adalah produk samping dari pengolahan jus jeruk berupa biji (Yilmaz dan Karaman, 2017), bagian batang brokoli sisa pengolahan berupa brokoli co-products (Lafarga et al., 2018), produk samping pengolahan minuman bunga rosela (Hibiscus sabdariffa Residue) (HSR) (Ahmed dan Abozed, 2015) dan produk samping pengolahan jus berry berupa blackcurrant pomace (Schmidt et al., 2017).

Kemelimpahan bahan pangan perlu dikelola lebih baik, agar bahan pangan tidak terbuang siasia. Hal tersebut juga termasuk tindakan preservasi supaya kandungan gizinya tidak mengalami kerusakan. Sebagai upaya pemanfaatan bahan pangan yang melimpah, maka dapat dilakukan dengan melakukan aplikasi bahan pangan yang memiliki nilai gizi tertentu ke dalam suatu produk pangan. Maka dari itu, produk pangan memiliki keunggulan karena ada zat gizi tertentu. Hal ini sudah menjadi tren, karena masyarakat melakukannya untuk mengurangi resiko terkena penyakit (Demin et al., 2019).

Penambahan berbagai bahan pangan dilakukan sebagai upaya agar produk pangan memiliki nilai nutrisi yang tinggi, sehingga baik untuk kesehatan ketika dikonsumsi. Salah satunya dapat dilakukan pada produk snack berupa crackers karena memiliki kandungan gizi yang rendah. Crackers termasuk ke dalam kategori biskuit dan memiliki rasa netral, atau sedikit manis dan asin. Produk ini merupakan snack yang mudah dikonsumsi dalam segala aktivitas, disukai banyak kalangan karena memiliki daya simpan yang lebih lama, memiliki rasa yang variatif, harganya relatif murah, serta memiliki bentuk yang tipis dan renyah. Berdasarkan lapisan di dalamnya, crackers dibagi menjadi dua, yaitu flaky crackers yang memiliki bagian dalamnya berlapis-lapis, sedangkan non-flaky crackers yang bagian dalamnya tidak memiliki lapisan-lapisan (Picauly dan Tetelepta, 2016). Crackers memiliki kandung-an lemak yang sedang sebesar 14-25\% serta gula dan garam yang rendah sebesar 2\% (Mihiranie et al., 2017; Venkatachalam dan Nagarajan, 2017).

\section{HASIL DAN PEMBAHASAN}

\section{Kualitas Produk Pangan}

Konsumsi produk pangan jadi sangat disukai oleh masyarakat Indonesia, karena lebih praktis, harga relatif murah, tidak sulit untuk didapatkan, rasa yang bervariasi dan umur simpan produk yang panjang (Tarwendah, 2017). Hal ini menyebabkan kualitas dan keamanan pangan menjadi hal yang penting agar terjamin untuk dikonsumsi (Yaseen et al., 2017). Kualitas produk pangan yang terjamin akan berdampak pada penerimaan produk oleh konsumen.

Kualitas produk pangan di Indonesia, diatur dalam Standar Nasional Indonesia (SNI) (Midayanto dan Yuwono, 2014). SNI produk pangan berisikan syarat mutu yang diatur dan ditetapkan oleh Badan Standarisasi Nasional (BSN), seperti contoh produk non-flaky crackers diatur dalam SNI 2973:2011 oleh BSN pada tahun 2011. Di dalamnya, terdapat beberapa keriteria yang berupa keadaan fisik, kadar air, kadar protein, kadar asam lemak bebas, kadar cemaran logam dan kadar cemaran mikroba. Kriteria keadaan fisik terdiri dari bau, rasa dan warna; cemaran logam yang dilihat adalah cemaran timbal $(\mathrm{Pb})$, cadmium (Cd), timah (Sn), merkuri (Hg) dan arsen (As); dan cemaran mikroba yang diukur adalah cemaran coliform, Escherichia coli, Salmonella sp., Staphylococcus aureus, Bacillus aureus, serta cemaran kapang dan khamir (Badan Standarisasi Nasional, 2011).

\section{Non-Flaky Crackers}

Crackers adalah salah satu produk bakery dari industri makanan yang sangat diminati oleh 
banyak konsumen. Bentuknya yang tipis serta renyah menarik ekspektasi banyak konsumen (Venkatachalam dan Nagarajan, 2017). Produk pangan ini sering dikonsumsi sebagai snack oleh banyak kalangan. Kadar air yang rendah pada cemilan ini menyebabkan lamanya daya simpan produk, bahkan hingga berbulan-bulan. Crackers juga memiliki kandungan karbohidrat yang tinggi karena bahan dasarnya berupa tepung gandum (Seftiono et al., 2019).

Crackers di bagi ke dalam tiga bagian besar, yaitu soda crackers, savoury crackers dan chemically leavened crackers (Millar et al., 2017). Berdasarkan lapisan yang terletak di dalamnya, crackers dibagi menjadi dua, yaitu flaky crackers dan non-flaky crackers. Flaky crackers adalah crackers yang terdapat lapisan-lapisan di dalamnya, sedangkan non-flaky crackers adalah crackers yang tidak memiliki lapisan di dalamnya (Picauly dan Tetelepta, 2016).

Bahan dasar dari produk non-flaky crackers adalah tepung gandum yang mengandung protein berupa gluten yang terdiri dari gliadin dan glutenin, yang akan memengaruhi viskoelastisitas adonan selama proses pencampuran adonan (Yazar et al., 2017). Ketika proses pembentukan adonan, struktur protein berupa gluten akan membentuk ikatan hidrogen (train) yang dapat memengaruhi ketahanan terhadap ekstensitas (Zheng et al., 2020).

Selama pencampuran adonan, jaringan gluten terbentuk dari depolimerisasi. Subunit glutenin yang dihubungkan dengan ikatan disulfida membentuk polimer dan beragregasi membentuk makropolimer glutenin, yang kemudian mengalami depolimerisasi menjadi agregat kecil, selama proses pengadonan. Depolimerisasi yang terjadi karena adanya hidrasi air pada glutenin selama proses pengadonan. dengan adanya hidrasi ini, serta memengaruhi re-polimerisasi beberapa agregat kecil gluten yang sebelumnya terlepas membentuk jaringan tiga dimensi, yang distabilisasi ikatan disulfida (Thiele et al., 2004). Repolimerisasi yang terjadi merupakan polimerisasi dari struktur polimer sulfihidril yang memiliki berat molekul rendah, yaitu glutation dan sistein selama pengadonan (Lambrecht et al., 2016). Repolimerisasi yang terjadi dapat dilihat pada Gambar 1.

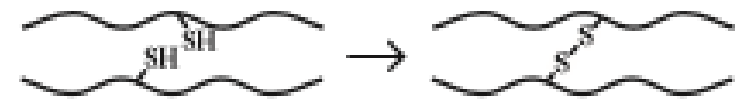

Gambar 1. Reaksi Re-polimerisasi polimer pada adonan crackers (Lallemand, 2018).
Tahapan setelah pembentukan adonan adalah fermentasi yang melibatkan penggunaan agen pengembang berupa ragi (Ismawati et al., 2019), yang akan memanfaatkan enzim yang ada di dalam tepung berupa $\alpha$-amilase (Rani et al., 2001). Enzim ini akan menghidrolisis pati menjadi glukosa (Sigechi et al., 2004), sehingga glukosa bisa difermentasi oleh ragi yang akan memecah gula menjadi alkohol dan gas $\mathrm{CO}_{2}$, serta menurunkan $\mathrm{pH}$ dalam adonan menjadi 4,7-4,8. Gas $\mathrm{CO}_{2}$ yang dihasilkan akan mengisi ruang kosong dan menyebabkan pengembangan ( $\mathrm{Xu}$ et al., 2019). Struktur ruang dalam adonan meregang dan mengalami peningkatan porositasnya dari 0,1 0,7 (Sandoval et al., 2017). Fermentasi adonan juga akan terjadi amilolitik, yang akan mendegradasi pati dan menyebabkan perubahan struktur pati, yang akan membuat struktur granula pati tergelatinisasi (Katina et al., 2005).

Saat fermentasi pada adonan, terjadi penurunan $\mathrm{pH}$ yang menyebabkan terbentuknya suasana $\mathrm{pH}$ yang optimum bagi enzim endogen berupa protease aktif bekerja (dalam rentang 6,92,8) (Capuani et al., 2013). Enzim tersebut akan menghidrolisis gluten pada tepung membentuk peptida dengan berat molekuler lebih rendah (Thiele et al., 2004). Hal ini akan berdampak pada penurunan peregangan pada adonan (Rezaei et al., 2016), karena ikatan disulfida yang sudah berkurang saat degradasi (Poutanen et al., 2009) dan dapat membentuk struktur adonan yang diinginkan.

Adonan yang sudah difermentasi akan dipipihkan, dipotong dan dipanggang (Olagunju et al., 2018). Pemipihan adonan berfungsi untuk mengurangi ketebalan adonan tanpa merusak matriks adonan (Filipčev et al., 2013), serta pemanggangan menggunakan suhu yang tinggi, dapat menghilangkan kadar air dan menyebabkan protein terdenaturasi dan membuka lipatan protein, sehingga protein memadat (Lambrecht et al., 2016). Pemanggangan juga berfungsi untuk mengurangi kadar air karena selama pemanggangan air akan menguap melepas $\mathrm{CO}_{2}$ dan meninggalkan ruang kosong pada crackers. Rendahnya kadar air akan memengaruhi tekstur dari crackers, yaitu lebih mudah untuk patah sehingga kekuatan hancurnya lebih kecil, begitu pula sebaliknya, jika kadar air crackers terlalu tinggi, lebih cenderung untuk memiliki tekstur yang keras, serta meningkatkan kekuatan hancurnya (Yildiz et al., 2019). Tekstur yang mudah patah ini disebabkan oleh karena bagian dalam non-flaky crackers yang 
berporos seperti sel berisikan udara (Jakubczyk et al., 2008).

\section{Serat Pangan}

Serat termasuk ke dalam fraksi polimer karbohidrat penyusun tumbuhan, yang tidak dapat dicerna di dalam usus halus, serta terus lewat hingga sampai usus besar (Yilmaz dan Karaman, 2017). Berdasarkan kelarutannya pada air, serat dibagi menjadi dua, yaitu serat larut dan serat tidak larut (Cui et al., 2019). Serat larut ( $\beta$-glucan, psyllium, arabinoxylans, pektin, guar gum dan inulin) memiliki tiga ciri-ciri penting, yaitu larut dalam air, berkemampuan untuk membuat larutan menjadi kental dan bisa difermentasi. Serat tidak larut (lignin, selulosa dan beberapa hemiselulosa) memegang tiga ciri-ciri utama, yaitu tidak larut dalam air, mengurangi fermentasi dan menjadi komponen pembentuk feses karena tidak dapat dicerna dalam saluran pencernaan (Surampudi et al., 2016; López-Marcos et al., 2015). Struktur kimia berbagai jenis serat pangan larut dapat dilihat pada Gambar 2 dan serat pangan tidak larut dapat dilihat pada Gambar 3.

Serat pangan atau dietary fiber merupakan komponen pada makanan yang memiliki peran penting bagi kesehatan manusia (López-Marcos et al., 2015). The Academy of Nutrition and Dietetics menganjurkan asupan serat yang cukup untuk orang dewasa adalah sebanyak $14 \mathrm{~g}$ total per 1000 kkal, atau konsumsi harian sebesar $25 \mathrm{~g}$ untuk wanita dan $38 \mathrm{~g}$ untuk pria dewasa (Yilmaz dan Karaman, 2017). Jika kebutuhan konsumsi serat terpenuhi, maka beberapa manfaat kesehatan yang diperoleh adalah sebagai berikut:

1. Menjaga kesehatan saluran pencernaan dengan terbentuknya substansi seperti gel oleh serat larut yang berikatan dengan air, sehingga menyebabkan lambatnya pengosongan lambung dan mengontrol absorpsi nutrient. Serat tidak larut akan mengikat air seperti sponge yang kemudian akan membantu mendorong makanan yang sedang diproses di dalam usus melewati saluran pencernaan (Lunn dan Buttriss, 2007).

2. Penurunan kadar kolesterol yang disebabkan karena adanya pengikatan asam empedu oleh serat pangan, kemudian dikeluarkan dalam bentuk feses dan mengakibatkan adanya pengambilan kolesterol di dalam darah untuk pembentukan asam empedu yang baru (Capuano, 2017).
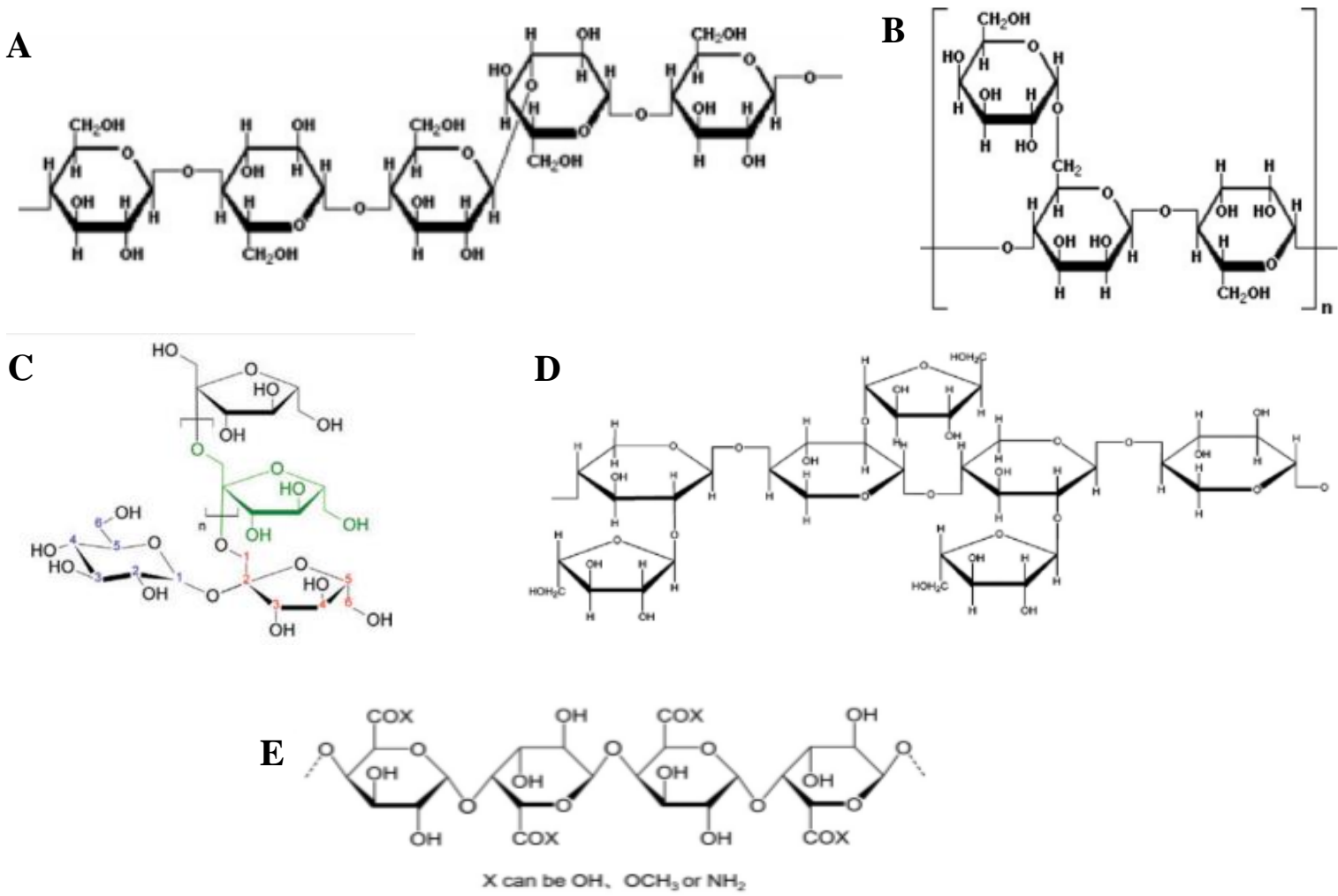

Gambar 2. Struktur kimia serat pangan larut: A) $\beta$-glucan; B) Guar gum; C) Inulin (Chawla dan Patil, 2010); D) Arabinoxylan (Sinha et al., 2011); dan E) Pektin (Cui et al., 2019) 
A
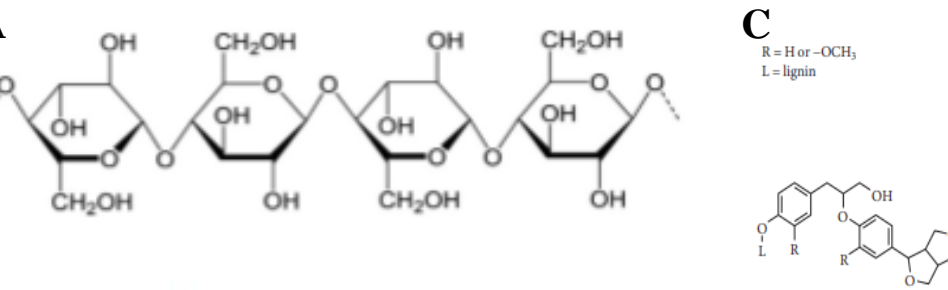

B
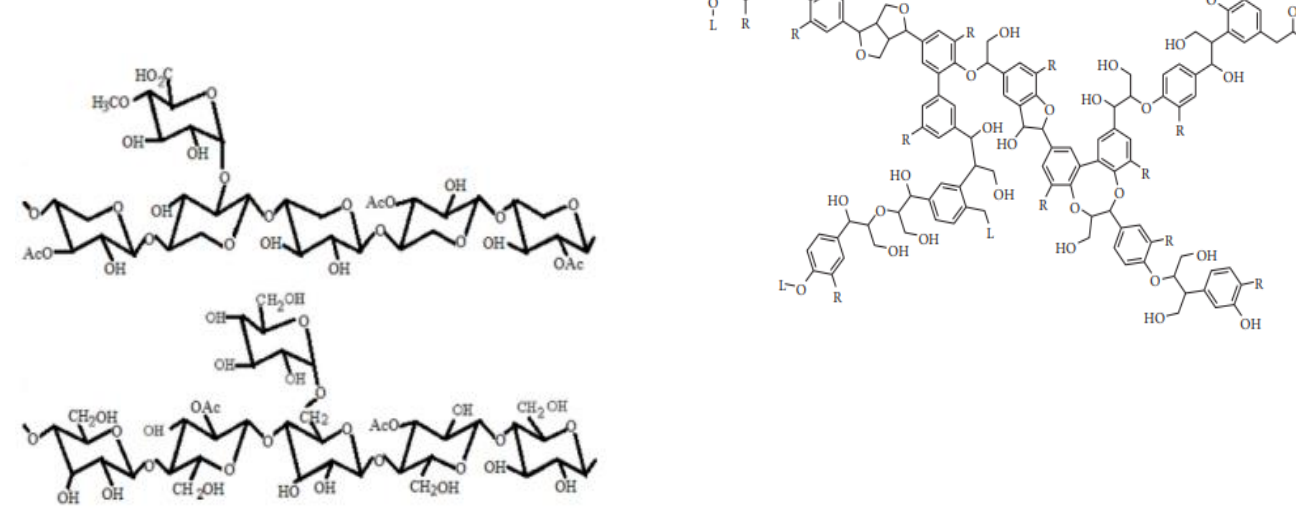

Gambar 3. Struktur kimia serat pangan tidak larut: A) Selulosa (Cui et al., 2019); B) Hemiselulosa (Tezara et al., 2016); dan C) Lignin (Lu et al., 2017)

3. Serat larut yang tidak dapat dicerna akan digunakan oleh mikroba (di dalam usus besar) sebagai bahan fermentasi menghasikan gas karbondioksida berkadar rendah dan asam lemak rantai pendek (SCFA). Hasil fermentasi menyebabkan adanya penurunan $\mathrm{pH}$ yang dapat menghambat pertumbuhan bakteri pathogen (Dahl dan Stewart, 2015). Asam lemak rantai pendek yang dihasilkan adalah propionat, butirat dan asetat. Propionat dan asetat akan diserap ke pembuluh darah portal hati yang mencegah pembentukan kolesterol hati, sedangkan butirat akan dimanfaatkan oleh kolonosit sebagai sumber energi (Gunnes dan Gidley, 2010).

4. Menurunkan resiko terkena diabetes dengan meningkatnya metabolisme glukosa karena adanya penumpukan serat pangan di lambung yang memperlambat pengosongannya, serta peningkatan rasa kenyang (Satija dan $\mathrm{Hu}$, 2012).

\section{Bahan Pangan Alami Sumber Serat Pangan}

Perlu adanya konsumsi serat pangan untuk mendapatkan manfaat-manfaat tersebut. Pemenuhan kebutuhan serat pangan, dapat dilakukan dengan mengonsumsi serealia, sayur-sayuran, buah-buahan dan kacang-kacangan karena serat umumnya terkandung di dalam bahan-bahan tersebut (Cui et al., 2019). Selain dari bahan-bahan tersebut, serat pangan juga bisa diperoleh dari produk samping (byproduct) dari pengolahan bahan pangan (Tarazona-Díaz dan Aguayo, 2013).
Beberapa contoh bahan pangan alami yang mengandung serat diantaranya adalah sebagai berikut.

\section{Kacang-kacangan}

\section{Kacang polong}

Kacang polong (Pisum sativum L.) merupakan salah satu jenis kacang-kacangan yang memiliki kandungan protein dan energi yang tinggi (Nalle et al., 2011). Kacang polong memiliki senyawa fenolik yang berada di kulit biji yang dapat bertindak sebagai antioksidan (Dahl, et al., 2015). Dalam 100 gramnya, kacang polong memiliki kandungan nutrisi berupa kadar air 12,62 g, abu 2,74 g, karbohidrat 52,78 g, lemak 2,63 g, protein $23,57 \mathrm{~g}$, serat pangan $18,28 \mathrm{~g}$ dan energi $329 \mathrm{kkal}$ (Frias et al., 2011).

\section{Bahan berklorofil tinggi}

\section{Mikroalga}

Mikroalga merupakan alga atau berjenis rumput laut dengan ukuran yang mikroskopis, yang berfotosintesis menggunakan cahaya matahari serta gas karbondioksida (Sani et al., 2014). Beberapa contoh mikroalga diantaranya adalah Arthrospira platensis yang memiliki kandungan senyawa biokimia berupa kandungan protein $68,9 \%$, karbohidrat $12,8 \%$, abu $6,1 \%$, lemak 10,7\%, sodium 0,6\% (Batista et al., 2019) dan serat kasar 6,2-11,9\% dalam biomassa berat keringnya (Cuellar-Bermúdez, 2017). 


\section{Byproducts}

\section{Biji Jeruk (Byproduct)}

Byproduct dari jeruk (Citrus sp.) adalah produk samping berupa biji, pulp dan kulit buah hasil pengolahan industri dalam pengolahannya menjadi jus buah alami, permen dan ekstrak daging buah, yang limbahnya mencapai 50\% dari buah (Jorge et al., 2016). Perlu adanya pemanfaatan limbah yang dihasilkan karena masih terdapat nutrisi yang bisa dimanfaatkan untuk kesehatan seperti pada biji jeruk. Kandungan komponen pada biji jeruk, terdapat kadar air sebesar 4,43-7,64\%, kadar lemak 20,99-32,17\%, protein $13,74-16,21 \%$, kadar abu $3,24-4,51 \%$ dan kadar serat pangan tidak larut sebesar 16,3829,97\% (Juhaimi et al., 2016).

\section{Batang Brokoli (Broccoli co-products)}

Brokoli (Brassica oleracea L. var. italica) adalah sayuran dan termasuk ke dalam family Brassicaceae atau kubis-kubisan, yang memiliki nutrisi tinggi, terutama kalsium, $\beta$-karoten, vitamin A, vitamin $\mathrm{K}$, antioksidan, riboflavin dan zat besi. Dalam brokoli, terdapat senyawa yang bersifat sebagai antikanker berupa sulforaphane glucosinolate, glutathione-S-transferase dan quinone reductase (Kumar dan Srivastava, 2016). Kandungan kimia atau proksimat pada brokoli mentah dalam $100 \mathrm{~g}$ mengandung kadar gula total $1,7 \mathrm{~g}$, karbohidrat $6,64 \mathrm{~g}$, protein $2,82 \mathrm{~g}$, lemak $0,37 \mathrm{~g}$, kadar air $89,3 \mathrm{~g}$, energi total 34 kkal dan serat pangan sebesar 2,6 g (Owis, 2015).

\section{Hibiscus sabdariffa Residue}

HSR adalah produk sampingan pembuatan minuman dari kelopak bunga rosella $(H$. sabdariffa), yang pemanfaatannya masih kurang namun masih terdapat kandungan bioaktif di dalamnya (Amaya-Cruz et al., 2018). Komponen bioaktif di dalam HSR berupa kadar serat pangan yang tinggi sebesar $67,16 \%$ yang terdiri dari $18,44 \%$ serat larut dan $48,43 \%$ serat tidak larut, lalu terdapat kandungan fenolik 6,83 GAE mg/g, flavonoid 5,63 CE mg/g dan antosianin 2,47 mg C3G/g (Amaya-Cruz et al., 2019).

\section{Blackcurrant Pomace}

Blackcurrant pomace merupakan produk samping dari proses pengolahan buah blackcurrant (Ribes ningrum L.) yang hancur dan tersisa ketika disaring. Bahan ini masih memiliki kandungan senyawa polifenol dan senyawa bioaktif yang baik untuk kesehatan tubuh (Michalska et al., 2017). Blackcurrant pomace memiliki senyawa bioaktif berupa kadar serat pangan yang baik, terdiri dari serat pangan larut sebesar 25,1-30 g dan serat pangan tidak larut sebesar $46,9-47,4 \%$, serta kadar protein sebesar 11,1-13,3\%, lemak 5,9-10,8\%, abu 2,8-3,3\%, kadar air 3,2-7,5\% dan karbohidrat 69,871,9\% (Alba et al., 2018).

\section{Aplikasi Bahan Pangan Alami pada Non-Flaky Crackers Secara Kimiawi}

Secara umum non-flaky crackers dibuat dengan menggunakan bahan berupa $2 \%$ gula, $2 \%$ garam, 2\% bahan pengembang (ragi atau baking soda), 28,5\% air, $10 \%$ minyak sayur serta bahan utama berupa terigu. Berbagai bahan tersebut dicampur dengan bahan tambahan (Tabel 1), sampai terbentuk adonan yang kohesif, lalu didiamkan 30 menit sambil ditutup. Adonan kemudian dipipihkan hingga ketebalan $5 \mathrm{~mm}$ menggunakan pasta roller dan dipotong membentuk persegi berukuran $4 \mathrm{~cm}$, kemudian dipanaskan dalam oven pada suhu $180^{\circ} \mathrm{C}$ selama 11 menit (Ahmed dan Abozed, 2015; Batista et al., 2019; Venkatachalam dan Nagarajan, 2017). Produk ini dipilih karena dianggap dapat berfungsi sebagai vektor yang dapat meningkatkan serat pangan dan komponen bioaktif lainnya bagi para konsumen (Schmidt et al., 2017). Pengaruh aplikasi penambahan bahan pangan alami pada non-flaky crackers secara kimiawi dapat dilihat pada Tabel 2.

Kadar air maksimum pada non-flaky crackers adalah 5\% dalam SNI 2973:2011 (Badan Standarisasi Nasional, 2011). Non-flaky crackers dengan tambahan biji jeruk 2,9\% dan biomassa mikroalga $A$. platensis $2 \%$ masih ada dalam ambang batas, yaitu sebesar $1,92 \%$ dan $4,1 \%$. Kadar air pada non-flaky crackers dengan penambahan kacang polong $40 \%$ sebesar $16,5 \%$, non-flaky crackers dengan penambahan coproducts dari brokoli $12,5 \%$, yaitu sebesar $9,44 \%$ dan pada non-flaky crackers dengan penambahan HSR $5 \%$ sebesar $6,28 \%$, yang menandakan bahwa kedua produk ini jauh di atas batas yang telah ditetapkan dalam SNI 2973:2011. Kadar air memiliki hubungan dengan kadar serat, yaitu tingginya kadar air pada non-flaky crackers disebabkan oleh karena adanya penambahan serat pangan dari bahan pangan yang ditambahkan memiliki sifat yang dapat mengikat air (Schmidt et al., 2017). 
Tabel 1. Besar prosentase berat penambahan bahan pangan alami pada produk non-flaky crackers

\begin{tabular}{|c|c|c|c|c|c|c|c|}
\hline No. & Bahan Pangan Alami & Perlakuan & $\begin{array}{c}\text { Komposisi Tepung } \\
\text { Gandum }\end{array}$ & \multicolumn{4}{|c|}{$\begin{array}{c}\text { Prosentase Tambahan Bahan } \\
\text { Pangan }\end{array}$} \\
\hline 1. & $\begin{array}{l}\text { Kacang polong (Millar } \\
\text { et al., 2017). }\end{array}$ & Subtitusi & $100 \%$ & $40 \%$ & & & \\
\hline 2. & $\begin{array}{l}\text { Mikroalga (Batista } e t \\
\text { al., 2019) }\end{array}$ & Subtitusi & $60,5 \%$ & $2 \%$ & $6 \%$ & & \\
\hline 3. & $\begin{array}{l}\text { Biji Jeruk (Yilmaz dan } \\
\text { Karaman, 2019)* }\end{array}$ & Penambahan & $57,14 \%$ & $2,9 \%$ & & & \\
\hline 4. & $\begin{array}{l}\text { Brokoli co-products } \\
\text { (Lafarga } \text { et al., 2018) }\end{array}$ & Subtitusi & UN & $12,5 \%$ & $15 \%$ & & \\
\hline 5. & $\begin{array}{l}\text { Hibiscus sabdariffa } \\
\text { Residue (HSR) (Ahmed } \\
\text { dan Abozed, 2015) }\end{array}$ & Subtitusi & $100 \%$ & $1,25 \%$ & $2,5 \%$ & $3,75 \%$ & $5 \%$ \\
\hline 6. & $\begin{array}{l}\text { Blackcurrant pomace } \\
\text { (BP) (Schmidt et al., } \\
\text { 2017) }\end{array}$ & Penambahan & $50 \%$ & $10 \%$ & $20 \%$ & $30 \%$ & \\
\hline
\end{tabular}

Tabel 2. Kandungan serat pangan pada non-flaky crackers yang sudah ditambahkan beberapa bahan pangan alami

\begin{tabular}{|c|c|c|c|c|c|c|}
\hline No. & Bahan Utama & Air & Abu & Protein & Lemak & Serat Pangan \\
\hline 1. & $\begin{array}{l}\text { Kontrol (tepung gandum) } \\
\text { (Olagunju et al., 2018) }\end{array}$ & NT & $1,78 \%$ & $9,32 \%$ & $21,39 \%$ & $2,90 \%$ \\
\hline 2. & $\begin{array}{l}\text { Kacang polong } 40 \% \text { (Millar et } \\
\text { al., 2017) }\end{array}$ & $16,15 \%$ & NT & $11,50 \%$ & NT & $11,08 \%$ \\
\hline 3. & 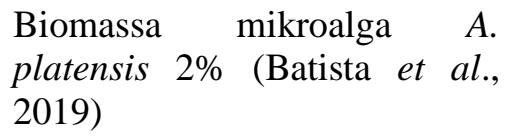 & $4,1 \%$ & $3,4 \%$ & $11 \%$ & $12,5 \%$ & $5,6 \%$ \\
\hline 4. & $\begin{array}{l}\text { Biji jeruk 2,9\% (Yilmaz dan } \\
\text { Karaman, 2019) }\end{array}$ & $1,92 \%$ & $1,74 \%$ & $11 \%$ & $14,88 \%$ & $6,89 \%$ \\
\hline 5. & $\begin{array}{l}\text { Brokoli co-products } 12,5 \% \\
\text { (Lafarga et al., 2018) }\end{array}$ & $9,44 \%$ & NT & NT & NT & $8,15 \%$ \\
\hline 6. & $\begin{array}{l}\text { Hibiscus sabdariffa residue 5\% } \\
\text { (Ahmed dan Abozed, 2015) }\end{array}$ & $6,28 \%$ & $3,38 \%$ & $9,70 \%$ & $5,30 \%$ & $8,17 \%$ \\
\hline 7. & $\begin{array}{l}\text { Blackcurrant pomace (BP) } \\
\text { (Schmidt et al., 2017) }\end{array}$ & NT & NT & NT & NT & NT \\
\hline
\end{tabular}

Keterangan: NT: Not Tested

Kadar protein pada produk non-flaky crackers tertinggi ada pada produk dengan penambahan kacang polong $40 \%$ yaitu sebesar $11,50 \%$. Namun, produk non-flaky crackers kontrol memiliki kadar protein yang paling rendah, yaitu sebesar $9,32 \%$. Kadar protein yang rendah ini disebabkan karena tidak ada penambahan bahan pangan yang dapat meningkatkan nilai proteinnya, jika dibandingkan dengan kacang polong yang memiliki kandungan protein sebesar 23,57 g dalam $100 \mathrm{~g}$ (Frias et al., 2011).
Kadar lemak tertinggi pada produk non-flaky crackers penambahan biji jeruk 2,9\%, yaitu sebesar $14,88 \%$, sedangkan lemak terendah ada pada non-flaky crackers penambahan HSR 5\%, yaitu sebesar $5,30 \%$. Tingginya kadar lemak pada non-flaky crackers dari biji jeruk disebabkan karena kandungan lemak dari biji jeruk sebesar 20,99-32,17\% (Juhaimi et al., 2016). Rendahnya kadar lemak pada non-flaky crackers penambahan HSR disebabkan oleh karena lemak pada kelopak bunga Hibiscus sabdariffa dalam $100 \mathrm{~g}$ hanya berkontribusi sebesar $0,1 \mathrm{~g}$ (Okereke et al., 2016). 
Tabel 3. Karakteristik adonan non-flaky crackers mengandung Blackcurrant Pomace (BP)

\begin{tabular}{ccc}
\hline Formulasi & Ekstensibilitas Adonan $(\mathbf{m m})$ & Resistensi Adonan $(\mathbf{N})$ \\
\hline Kontrol & $23,75^{\mathrm{a}} \pm 2,49$ & $0,27^{\mathrm{a}} \pm 0,03$ \\
BP 10\% & $24,01^{\mathrm{a}} \pm 1,06$ & $0,23^{\mathrm{b}} \pm 0,02$ \\
BP 20\% & $20,51^{\mathrm{b}} \pm 1,04$ & $0,21^{\mathrm{c}} \pm 0,02$ \\
BP 30\% & $16,41^{\mathrm{c}} \pm 1,23$ & $0,20^{\mathrm{c}} \pm 0,02$ \\
\hline
\end{tabular}

Sumber: Schmidt et al. (2017).

Terjadi peningkatan kadar serat pangan pada setiap produk jika dibandingkan dengan non-flaky crackers kontrol yang hanya sebesar $2,9 \%$. Pada produk non-flaky crackers dengan penambahan kacang polong $40 \%$ memiliki kadar serat paling tinggi, yaitu sebesar $11,08 \%$, karena bahan pangan kacang polong memiliki kandungan serat sebesar 18,28 g dalam $100 \mathrm{~g}$ (Frias et al., 2011). Kadar serat pangan paling rendah diperoleh oleh produk non-flaky crackers dengan penambahan biomassa mikroala A. platensis yaitu sebesar $5,6 \%$, karena $A$. platensis memiliki kandungan serat kasar 6,211,9\% (Cuellar-Bermúdez, 2017).

\section{Pengaruh Aplikasi Bahan Pangan Alami Terhadap Elastisitas Adonan Non-Flaky Crackers}

Elastisitas adonan sangat diperlukan dalam pembuatan non-flaky crackers. Adonan yang elastis lebih mudah untuk dibentuk, baik dalam pembentukan layer atau lapisan yang pipih, maupun lebih mudah untuk dipotong (Oliver dan Brock, 1997). Adonan yang sudah dipipihkan menyebabkan penambahan luas permukaan dari adonan, sehingga selama pemanggangan dapat menguapkan air pada adonan secara maksimal. Hal ini menghasilkan karakteristik kepingan non-flaky crackers yang renyah (Kweon et al., 2014).

Beberapa penambahan bahan pangan berupa kacang polong, mikroalga A. platensis, biji jeruk, brokoli co-product dan HSR yang diaplikasikan ke dalam non-flaky crackers memang memberikan manfaat baik dalam segi zat gizi. Akan tetapi, ada penurunan terhadap elastisitas adonan non-flaky crackers. Hal ini disebabkan karena adanya bahan pengganti yang dikomposisikan pada adonan (Dokić et al., 2015). Seperti pada penambahan blackcurrant pomace dalam adonan non-flaky crackers, memberikan efek pada adonan yang dapat dilihat pada Tabel 3.

Pemberian blackcurrant pomace pada adonan non-flaky crackers menunjukkan hasil bahwa adanya peningkatan yang tidak beda nyata pada ekstensibilitas adonan crackers penambahan blackcurrant pomace 10\%. Penambahan black currant pomace sebesar 20 dan $30 \%$ berikutnya menunjukkan adanya penurunan yang beda nyata. Penurunan ekstensibilitas adonan disebabkan oleh karena penurunan komposisi gluten dalam tepung. Penurunan ini berhubungan dengan pembentukan struktur dalam adonan, menyebabkan penyerapan air oleh gluten juga berkurang (Schmidt et al., 2017).

Serat pangan pada bahan tambahan dan gluten akan saling menyerap air yang tersedia ketika proses pengadonan. Penyerapan air yang tinggi dari sumber serat akan menahan proses pembentukan jaringan protein, menyebabkan jaringan protein yang tidak terbentuk berdampak pada penurunan daya patah non-flaky crackers, sehingga kualitas tekstur bisa menurun (Li et al., 2014). Serat tidak larut (selulosa, hemiselulosa dan lignin) dari bahan pomace akan melakukan interaksi dengan matriks gluten dengan ikatan hidrogen dan membuat adonan menjadi kaku atau sebagai pengisi dari matriks viskoelastisitas (Struck et al., 2018). Kandungan serat tidak larut seperti selulosa dan lignin bertindak sebagai penghalang fisik, serta menghambat penyerapan air oleh gluten. Hal ini memberikan efek pada adonan menjadi kurang mengembang karena ekstensibilitasnya juga berkurang (Abebe et al., 2015).

\section{Pengaruh Aplikasi Bahan Pangan Alami Terhadap Tekstur Non-Flaky Crackers}

Tekstur adalah parameter yang diukur secara sensoris yang mengukur sifat mekanis makanan yang masuk ke dalam mulut dan reaksi makanan setelah diberi kekuatan yang diterapkan ketika makanan dikunyah. Tekstur dari non-flaky crackers ketika dikonsumsi adalah renyah (Civille, 2011), karena kadar air yang rendah dan bagian dalam non-flaky crackers yang berporos seperti sel berisikan udara (Jakubczyk et al., 2008). Oleh karena itu, kerenyahan menjadi hal yang perlu diperhatikan dalam pembuatan non-flaky crackers karena sangat mempengaruhi penerimaan produk 
bagi masyarakat (Venkatachalam dan Nagarajan, 2017).

Penerimaan produk bisa diketahui dengan dilakukan uji secara organoleptik. Uji organoleptik dilakukan dengan menyiapkan produk kontrol dan beberapa produk yang sudah diberikan formula penambahan bahan (Seftiono et al., 2019). Produk tersebut kemudian diberikan pada panelis untuk dirasakan dan dinilai teksturnya dari skala paling rendah sebagai nilai sangat tidak suka sampai skala paling tinggi sebagai nilai sangat suka (Isik dan Topkaya, 2016).

Produk non-flaky crackers yang ditambahkan biomassa mikroalga A. platensis yang ditambahkan sebesar $2 \%$ menunjukkan penilaian kesukaan tekstur yang menurun, namun tidak beda nyata dan hampir mendekati produk kontrol. Penurunan yang tidak signifikan ini disebabkan karena kadar air dari produk $(4,1 \pm 0,1 \%)$ meningkat, namun tidak beda nyata dengan kadar air kontrol $(3,7 \pm 0,1 \%)$ (Batista et al., 2019). Kadar air yang lebih tinggi akan memengaruhi pembentukan struktur adonan yang kurang menyatu dapat menyebabkan adanya kehilangan kerenyahan (Hao et al., 2016).

Tekstur produk non-flaky crackers dengan HSR sebanyak 5\% menunjukkan adanya peningkatan yang beda nyata dibandingkan produk kontrol. Penilaian tekstur produk non-flaky crackers penambahan HSR memiliki kadar air yang lebih rendah yaitu sebesar $6,28 \%$ jika dibandingkan produk kontrol yang lebih tinggi, yaitu 8,30\% (Ahmed dan Abozed, 2015). Produk tersebut memiliki kadar air yang lebih rendah dibandingkan kontrol menyebabkan adanya peningkatan kerenyahan. Kadar air yang rendah akan berkaitan dengan tekstur, yang jika kadar air rendah akan memengaruhi harapan konsumen untuk mendapatkan kekerasan dan tekstur tertentu. Jika kadar air terlalu rendah akan berdampak pada penurunan penerimaan oleh konsumen (Carter et al., 2015).

\section{Pengaruh Aplikasi Penambahan Bahan Pangan Alami Terhadap Warna Non-Flaky Crackers}

Non-flaky crackers kontrol yang tidak diberikan penambahan bahan memiliki warna cerah kekuningan, yang berasal dari proses pemanggangan (Yilmaz dan Karaman, 2017). Ketika dalam proses pemanggangan, terjadi reaksi Maillard, yang melibatkan asam amino dan gula pereduksi. Reaksi Maillard juga dipicu dengan adanya suhu tinggi (biasanya lebih dari $70^{\circ} \mathrm{C}$ ), sehingga terbentuk senyawa melanoidin yang menghasilkan warna cokelat (Benzing-Purdie et al., 1985; Martins et al., 2000).

Warna akhir pada non-flaky crackers dapat dipengaruhi dengan adanya penambahan bahan pangan alami. Pengaruh warna merupakan salah satu parameter yang diujikan dengan menggunakan panelis menggunakan uji organoleptik (Mihiranie et al., 2017). Panelis diberikan sampel produk yang sudah diberikan kode acak, kemudian memberikan nilai terhadap warna dari produk dengan nilai paling rendah yang menandakan "paling tidak disukai" dan nilai paling tinggi menandakan "paling disukai" (Lafarga et al., 2018).

Produk non-flaky crackers dengan penambahan kacang polong $40 \%$ menunjukkan adanya peningkatan yang tidak signifikan daripada produk kontrol. Warna dari tepung kacang polong berkontribusi meningkatkan rona hijau (Millar et al., 2017). Penambahan bahan berupa tepung kacang polong yang tinggi protein dan gula (Frias et al., 2011) akan mempengaruhi peningkatan reaksi Maillard (Rampersad et al., 2003), yang menyebabkan adanya peningkatan warna dan disukai oleh panelis.

Penambahan biomassa A. platensis sebesar $2 \%$ pada non-flaky crackers menunjukkan adanya penurunan nilai warna dari produk kontrol yang "disukai" menjadi "agak disukai". Penambahan biomassa A. platensis menyebabkan adanya perubahan warna non-flaky crackers menjadi warna hijau agak gelap, karena kandungan pigmen warna hijau klorofil yang terkandung di dalamnya (Batista et al., 2019). Kandungan klorofil yang mengalami proses pemanasan akan terdegradasi membentuk pheophytin yang membuat perubahan warna yang tidak diinginkan dari hijau terang menjadi agak cokelat kehijauan (Isleroglu et al., 2016).

Uji organoleptik produk non-flaky crackers penambahan 5\% menunjukkan penurunan nilai kesukaan warna yang beda nyata jika dibandingkan dengan kontrol. Akan tetapi, pada produk nonflaky crackers dengan penambahan HSR sebesar $1,25 \%$ dan $2 \%$ menunjukkan penurunan nilai yang tidak beda nyata dengan kontrol (Ahmed dan Abozed, 2015). Penambahan tepung yang berasal dari bahan produk samping yang dikeringkan akan menyebabkan penurunan kecerahan (Isik dan Topkaya, 2016), yang menyebabkan penambahan HSR 5\% kurang disukai panelis dibandingkan dengan penambahan HSR 1,25\% dan 2\%. 


\section{Pengaruh Aplikasi Penambahan Bahan Pangan Alami Terhadap Cita Rasa Non-Flaky Crackers}

Cita rasa asin dari produk non-flaky crackers diperoleh karena adanya komposisi berupa garam sebanyak 1\% dari total bahan (Millar et al., 2017). Ketika adanya penambahan bahan lain, dapat memengaruhi cita rasa dari non-flaky crackers itu sendiri (Venkatacahalam dan Nagarajan, 2017). Penambahan bahan yang diaplikasikan pada nonflaky crackers diketahui dengan melakukan evaluasi sensoris atau uji organoleptik, dengan keterlibatan panelis (Seftiono et al., 2019). Hal ini perlu dilakukan karena citarasa menjadi salah satu parameter penting bagi konsumen untuk menentukan kualitas non-flaky crackers (Ihab et al., 2019).

Cita rasa produk non-flaky crackers dengan penambahan A. platensis yang menunjukkan penurunan menjadi "agak disukai" dari nilai "disukai" pada produk kontrol. Akan tetapi, Sebagian besar panelis menilai cita rasa produk masih ideal bagi panelis (Batista et al., 2019). Penambahan A. platensis akan mempengaruhi rasa dari produk karena merupakan alga air laut, yang memiliki bau amis dan ada rasa seperti rumput laut. Penambahan 2,5\% memberi sedikit pengaruh, sedangkan penambahan di atas 5\% akan menimbulkan cita rasa yang tidak diinginkan pada produk (Nakib et al., 2019).

Uji organoleptik pada non-flaky crackers dengan penambahan biji jeruk sebesar 2,9\%, menunjukkan penurunan yang beda nyata daripada non-flaky crackers kontrol. Rendahnya nilai pada biji jeruk disebabkan oleh karena terkandung senyawa flavonoid berupa naringenin (Tutunchi et al., 2020), yang memiliki rasa pahit (Russo et al., 2014). Senyawa flavonoid tersebut mampu menurunkan aktivitas enzim $\alpha$-amilase sehingga menghambat hidrolisis pati mengurai glukosa dan menimbulkan rasa pahit (Iskandar et al., 2019). Rasa pahit ini yang menjadi pembatas dalam mengaplikasikan biji jeruk pada non-flaky crackers (Yilmaz dan Karaman, 2017), sehingga perlu adanya penelitian lebih lanjut dalam pembuatan komposisi dalam produk untuk mengatasi hal tersebut.

Produk non-flaky crackers dengan penambahan HSR sebanyak 5\% menunjukkan adanya penurunan yang beda nyata jika dibandingkan dengan kontrol, namun ada peningkatan yang beda nyata pada penambahan HSR $1,25 \%$ dan $2,5 \%$ (Ahmed dan Abozed, 2015). Peningkatan cita rasa non-flaky crackers disebabkan karena ada sedikit rasa manis, asam, pahit dan sepat (Mounigan dan
Badrie, 2006) pada filtrat dari pembuatan minuman rosella (Amaya-Cruz et al., 2018) yang menimbulkan rasa yang disukai oleh panelis. Jika konsentrasinya meningkat menimbulkan adanya pahit dan sepat yang meningkat, menyebabkan penurunan kesukaan terhadap cita rasa oleh panelis.

\section{Pengaruh Aplikasi Penambahan Bahan Pangan Alami Terhadap Masa Simpan Non-Flaky Crackers}

Masa simpan merupakan lamanya waktu penyimpanan bagi makanan, sampai makanan dianggap tidak layak lagi untuk dikonsumsi (Sirpatrawan, 2009). Masa simpan pada makanan, sangat memengaruhi kualitas makanan, termasuk non-flaky crackers. Produk ini memiliki masa simpan yang lama, yaitu bisa beberapa minggu bahkan hingga dalam hitungan bulan. Lamanya penyimpanan ini disebabkan karena kandungan air pada non-flaky crackers yang rendah, yaitu maksimum 5\% setiap $100 \mathrm{~g}$ (Seftiono et al., 2019).

Produk non-flaky crackers dengan penambahan biji jeruk 2,9\% diuji penyimpanannya selama 90 hari. Selama penyimpanan kadar $a_{w}$ pada produk mengalami peningkatan pada hari ke15 kemudian menurun sampai hari ke-90. Kadar $a_{w}$ produk pada awal penyimpanan rendah, yaitu sebesar 0,11, lalu penyimpanan hari ke-90, kadar $\mathrm{A}_{\mathrm{w}}$ menurun menjadi 0,1 (Yilmaz dan Karaman, 2017). Produk non-flaky crackers dengan penambahan A. platensis $2 \%$ diuji masa simpan selama 8 minggu. Pada awal pengujian, diperoleh kadar $a_{w}$ sebesar 0,155 kemudian mengalami peningkatan sampai minggu ke-8 mencapai 0,362 (Batista et al., 2019).

Kadar $a_{w}$ yang dianjurkan untuk makanan bertipe kering seperti crackers dan cookies adalah tidak lebih dari 0,3 untuk menjaga stabilitas produknya (Tarancón et al., 2013). Kadar $a_{w}$ yang ditunjukkan oleh kedua produk masih rendah, sehingga dapat menekan pertumbuhan mikrobia, sehingga menghindari kontaminasi dari mikroba patogen dan bisa memperpanjang masa simpannya (Ijabadeniyi dan Pillay, 2017). Jika kadar $a_{w}$ rendah, kadar air yang ada pada produk juga rendah, sehingga dapat menjaga kerenyahan nonflaky crackers (Mihiranie et al., 2017).

\section{KESIMPULAN}

Pemanfaatan bahan pangan alami memang memberikan peningkatan nilai gizi suatu produk pangan, yang salah satu contohnya adalah serat 
pangan. Bahan-bahan alami yang ditambahkan pada produk non-flaky crackers memiliki potensi untuk meningkatkan nilai gizinya, terutama serat pangan yang sangat penting bagi kesehatan manusia. Bahkan, beberapa produk sampingan dari produksi suatu bahan pangan juga masih berpotensi untuk menyumbang nilai gizi non-flaky crackers. Hal ini dapat dilihat dengan adanya kenaikan kadar serat pangan, yang lebih tinggi dibandingkan dengan produk kontrolnya. Penambahan bahan pangan alami juga memberikan pengaruh berupa penerimaan secara sensoris, terkait tekstur, warna, citarasa dan masa simpan. Perlu adanya komposisi serta penambahan jenis bahan pangan yang tepat dalam pembuatan nonflaky crackers dengan penambahan berbagai bahan alami, agar nilai gizinya meningkat namun juga dapat diterima oleh konsumen dari segala aspek.

\section{DAFTAR PUSTAKA}

Abebe, W., F. Ronda, M. Villanueva, and C. Collar. 2015. Effect of tef [Eragrostis tef (Zucc.) Trotter] grain flour addition on viscoelastic properties and stickiness of wheat dough matrices and bread loaf volume. European Food Research Technology 241: 469-478. DOI: 10.1007/ s00217-015-2476-0.

Ahmed, Z.S. and S.S. Abozed. 2015. Functional and antioxidant properties of novel snack crackers incorporated with Hibiscus sabdariffa by-product. Journal of Advanced Research 6: 79-87. DOI: 10.1016/j.jare.2014.07.002.

Alba, K., W. MacNaughtan, A.P. Laws, T.J. Foster, G.M. Campbell, and V. Kontogiorgos. 2018. Fractionation and charactherisation of dietary fibre from blackcurrant pomace. Food Hydrocolloids 81: 398-408. DOI: 10.1016/j.foodhyd. 2018.03.023.

Amaya, D.M., I.F. Perez-Ramirez, D. Ortega-Diaz, M.E. Rodriguez-Garcia, and R. ReynosoCamacho. 2018. Roselle (Hibiscus sabdariffa) by-product as functional ingredient: effect of thermal processing and particle size reduction on bioactive constituents and functional, morphological, and structural properties. Journal of Food Measurement and Characterization 12: 135 144. DOI: 10.1007/s11694-017-9624-0.

Amaya-Cruz, D., I.F. Peréz-Ramírez, J. PérezJiménez, and G.M. Nava. 2019. Comparison of the bioactive potential of roselle (Hibiscus sabdariffa L.) calyx and its byproduct: phenolic characterization by UPLC-QTOF MSE and their anti-obesity effect in vivo. Food Research International 126: 1-9. DOI: 10.1016/j.foodres.2019. 108589.

Badan Standarisasi Nasional. 1992. SNI 01-29731992 Tentang Biskuit. BSN, Jakarta.

Batista, A. P., A. Niccolai, I. Bursic, I. Sousa, A. Raymundo, L. Rodolfi, N. Biondi, and M.R. Tredici. 2019. Microalgae as functional ingredients in savory food products: application to wheat crackers. Foods 8: 122. DOI: $10.3390 /$ foods 8120611 .

Benzing-Purdie, L.M., J.A. Ripmeester, and C.I. Ratcliffe. 1985. Effects of temperature on Maillard reaction products. Journal of Agricultural and Food Chemistry 33: 31-33. DOI: 10.1021/jf00061a009.

Capuani, A., J. Behr, and R.F. Vogel. 2013. Influence of lactic acid bacteria on redox status and on proteolytic activity of buckwheat (Fagopyrum esculentum Moench) sourdough. International Journal of Food Microbiology 165: 148-155. DOI: 10.1016/j.ijfoodmicro.2013.04.020.

Capuano, E. 2017. The behavior of dietary fiber in the gastrointestinal tract determines its physiological effect. Critical Reviews in Food Science and Nutrition 57: 3543-3564. DOI: 10.1080/10408398.2016.1180501.

Carter, B.P., M.T. Galloway, G.S. Campbell, and A.H. Carter. 2015. The critical water activity from dynamic dewpoint isotherms as an indicator of crispness in low moisture cookie. Food Measure 9: 463-470. DOI: 10.1007/s11694-015-9254-3.

Chawla, R. and G.R. Patil. 2010. Soluble dietary fiber. Comprehensive Reviews in Food Science and Food Safety 9: 178-196. DOI: 10.1111/j.1541-4337.2009.00099.x.

Civille, G.V. 2011. Food texture: pleasure and pain. Journal of Agricultural and Food Chemistry 59: 1487-1490. DOI: 10.1021/ jf100219h.

Cuellar-Bermúdez, S.P., B. Barba-Davila, S.O. Serna-Saldivar, R. Parra-Saldivar, J. Rodriguez-Rodriguez, S. Morales-Davila, K. Goiris, K. Muylaert, and C. ChuckHernández. 2017. Deodorization of Arthrospira platensis biomass for further scale-up food application. Journal of the 
Science of Food and Agriculture 97: 51235130. DOI: $10.1002 /$ jsfa.8391.

Cui, J., Y. Lian, C. Zhao, H. Du, Y. Han, W. Gao, H. Xiao, and J. Zheng. 2019. Dietary fibers from fruits and vegetables and their health benefits via modulation of gut microbiota. Comprehensive Reviews in Food Science and Food Safety 18: 1514-1532. DOI: 10.1111/1541-4337.12489.

Dahl, W.J. and M. Stewart. 2015. Position of the academy of nutrition and dietetics: health implications of dietary fiber. Journal of the Academy of Nutrition and Dietetics 115: 1861-1870. DOI: 10.1016/j.jand.2015.09. 003

Dahl, W.J., L.M. Foster and R.T. Tyler. 2015. Review of the health benefits of peas (Pisum sativum L.). British Journal of Nutrition 108: S3-S10. DOI: 10.1017/S0007114512000852.

Demin, M., B. Rabrenovič, L. Pezo, and J. LaličičcPetronijevic. 2019. Influence of chia seeds (Salvia hispanica L.) and extra virgin olive oil addition on nutritional properties of salty crackers. Journal of Food Measurement and Characterization 14: 378-387. DOI: 10.1007/s11694-019-00300-7.

Dokić, L., I. Nijolić, D. Šoronja-Simović, Z. Šereš, B. Pajin, N. Juul, and N. Maravić. 2015. Rheological properties of dough and sensory quality of crackers with dietary fiber. International Journal of Biological, Biomolecular, Agricultural, Food and Biotechnological Engineering 9: 964-968.

Dokić, L., B. Pajin, A. Fišteš, Z. Šereš, D.Š. Simović, and V. Krstonošić. 2015. Rheological and textural properties of cracker dough with the addition of pea dietary fiber. Acta Periodica Technologica 46: 29-35. DOI: 10.2298/APT1546029D.

Filipčev, B., O. Simurina, M. Bodroža-Solarov, and J. Brkljača. 2013. Dough rheological properties in relation to cracker-making performance of organically grown spelt cultivars. International Journal of Food Science and Technology 48: 2356-2362. DOI: 10.1111/ijfs.12225.

Frias, J., S. Giacomino, E. Peñas, N. Pellegrino, V. Ferreyra, N. Apro, M.O. Carrión, and C. Vidal-Valverde. 2011. Assessment of the nutritional quality of raw and extruded Pisum sativum L. var. laguna seeds. LWTFood Science and Technology 44: 13031308. DOI: 10.1016/j.lwt.2010.12.025.
Gunnes, P. and M.J. Gidley. Mechanisms underlying the cholesterol-lowering properties of soluble dietary fibre polysaccharides. Food \& Function 1: 149155. DOI: $10.1039 / \mathrm{c} 0$ fo00080a,

Hao, F., L. Lu, and J. Wang. 2016. Finite element simulation of shelf-life prediction of moisture-sensitive crackers in permeable packaging under different storage condition. Journal of Food Processing and Preservation 40: 37-47. DOI: 10.1111/jfpp. 12581.

Ihab, A.M., R.K. Mohamed, W.M. Abozeid, and E.A. Abou-Arab. 2019. Physicochemical and sensory properties of oat crackers incorporated with cactus pear cladodes flour. Middle East Journal of Applied Sciences 9: 927-936. DOI: 10.36632/mejas/2019.9.4.10.

Ijabadeniyi, O.A. and Y. Pillay. 2017. Microbial safety of low water activity foods: study of simulated and durban household samples. Journal of Food Quality 1: 1-7. DOI: 10.1155/2017/4931521.

Isik, F. and C. Topkaya. 2016. Effects of tomato pomace supplementation on chemical and nutritional properties of crackers. Italian Journal of Food Science 28: 525-535. DOI: 10.14674/1120-1770\%2Fijfs.v510136.

Iskandar, S.G., Y.R. Swasti, dan Yanuarto. 2019. Penurunan glukosa darah mencit (Mus musculus) jantan hiperglikemia dengan variasi penambahan minuman serbuk biji alpukat (Persea americana Mill.). Jurnal Teknologi Pertanian 20: 153-162.

Isleroglu, H., M. Sakin-Yilmazer, T. KemerliKalbaran, A. Üren, and F. Kaymak-Ertekin. 2016. Kinetics of colour, chlorophyll and ascorbic acid content in spinach baked in different types of oven. International Journal of Food Properties 20: 2456-2465. DOI: 10.1080/10942912.2016.1240689.

Ismawati, R., M. Wahini, I.F. Romadhoni, and Q. Aina. 2019. Sensory preference, nutrient content, and shelf life of Moringa oliefera leaf crackers. International Journal on Advanced Science Engineering Information Technology 9: 489-494.

Jakubczyk, E., A. Marzec, and P.P. Lewicki. 2008. Relationship between water activity of crisp bread and its mechanical properties and structure. Polish Journal of Food and Nutrition Science 58: 45-51.

Jorge, N., A.C. da Silva, and C.P.M. Aranha. 2016. Antioxidant activity of oils extracted from 
orange (Citrus sinensis) seeds. Anais da Academia Brasileira de Ciências 88: 951958. DOI: 10.1590/00013765201620140562.

Juhaimi, F.A.L., B. Matthäus, M.M. Özcan, and K. Ghafoor. 2016. The physico-chemical properties of some citrus seeds and seed oils. Zeitschrift für Naturforschung - Section C Journal of Biosciences 71: 79-85. DOI: 10.1515/znc-2016-0004.

Katina, K., E. Arendt, K.H. Liukkonen, K. Autio, L. Flander, and K. Poutanen. 2005. Potential of sourdough for healthier cereal products. Trends in Food Science \& Technology 16: 104-112. DOI: 10.1016/j.tifs.2004.03.008.

Khatun, H., N. Jahan, M. Hosain, T. Mardy, and S. Rahman. 2016. Effect of papaya and storage time on the quality of the newly developed papaya crackers. Journal of Experimental Biology and Agricultural Sciences 4: 194200. DOI: 10.18006/2016.4(2).194.200.

Kumar, P. and D.K. Srivastava. 2016. Biotechnological advancement in genetic improvement of broccoli (Brassica oleracea L. var. italica), an important vegetable crop. Biotechnology Letters 38: 1049-1063. DOI: 10.1007/s10529-016-2080-9.

Kweon, M., L. Slade, H. Levine, and D. Gannon. 2014. Cookie- versus cracker-baking-what's the difference? Flour functionality requirements explored by SRC and alveography. Critical Reviews in Food Science and Nutrition 54: 115-138. DOI: 10.1080/10408398.2011.578469.

Lafarga, T., E. Gallagher, A. Bademunt, G. Bobo, G. Echeverria, I. Viñas, and I. AguilóAguayo. 2018. Physiochemical and nutritional characteristics, bioaccessibility and sensory acceptance of baked crackers containing broccoli co-products. International Journal of Food Science and Technology 54: 634-640. DOI: 10.1111/ijfs.13908.

Lallemand. 2018. Dough Reduction Chemistry A Guide to Reducing Agent. https://lallemandbaking.com/wpcontent/uploads/2018/04/3_7REDUCING.p df. Diakses: 27 September 2020.

Lambrecht, M.A., I. Rombouts, and J.A. Delcour. 2016. Denaturation and covalent network formation of wheat gluten, globular proteins and mixtures thereof in aqueous ethanol and water. Food Hydrocolloids 57: 122-131. DOI: 10.1016/j.foodhyd.2016.01.018.
Lasander, C. 2013. Citra merek, kualitas produk dan promosi pengaruhnya terhadap kepuasan konsumen pada makanan tradisional. Jurnal EMBA 1: 284-293.

Li, J., G.G. Hou, Z. Chen, and K. Gehring. 2014. Studying the effects of whole-wheat flour on the rheological properties and the quality attributes of whole-wheat saltine cracker using SRC, alveograph, rheometer, and NMR technique. LWT-Food Science and Technology 55: 43-50. DOI: 10.1016/j.lwt.2013.07.022.

López-Marcos, M.C., C. Bailina, M. ViudaMartos, J.A. Pérez-Alvarez, and J. Fernández-López. 2015. Properties of dietary fibers from agroindustrial coproducts as source for fiber-enriched foods. Food and Bioprocess Technology 8: 2400-2408. DOI: 10.1007/s11947-015-1591-z.

Lu, Y., Y.C. Lu, H.Q. Hu, F.J. Xie, X.Y. Wei, and X. Fan. 2017. Structural characterization of Lignin and its degradation products with spectroscopic methods. Journal of Spectroscopy 2017: 1-15. DOI: 10.1155/ $2017 / 8951658$.

Lunn, J. and J.L. Buttriss. 2007. Carbohydrates and dietary fibre. Nutrition Bulletin 32: 21-64. DOI: 10.1111/j.1467-3010.2007.00616.x.

Martins, S.I.F.S., W.M.F. Jongen, and M.A.J.S. Boekel. 2000. A review of Maillard reaction in food and implications to kinetic modelling. Trends in Food Science \& Technology 11: 364-373. DOI: 10.1016/S0924-2244(01)00022-X.

Michalska, A., A. Wojdyto, K. Lech, G.P. Łysiak, and A. Figiel. 2017. Effect of different drying techniques on physical properties, total polyphenols and antioxidant capacity of blackcurrant pomace powders. LWT-Food Science and Technology 78: 114-121. DOI: 10.1016/j.lwt.2016.12.008.

Midayanto, D.N. dan S.S. Yuwono. 2014. Penentuan atribut mutu tekstur tahu untuk direkomendasikan sebagai syarat tambahan dalam Standar Nasional Indonesia. Jurnal Pangan dan Agroindustri 2: 259-267.

Mihiranie, S., M. Jayasundera, and N. Perera. 2017. Development of snack crackers incorporated with defatted coconut flour. Journal of Microbiology, Biotechnology and Food Sciences 7: 153-159. DOI: 10.15414/jmbfs.2017.7.2.153-159.

Millar, K.A., C. Barry-Ryan, R. Burke, K. Hussey, S. McCarthy, and E. Gallagher. 2017. Effect 
of pulse flours on the physiochemical characteristics and sensory acceptance of baked crackers. International Journal of Food Science and Technology 52: 1-9. DOI: 10.1111/ijfs.13388.

Mounigan, P. and N. Badrie. 2006. Roselle/sorrel (Hibiscus sabdariffa L.) wines with varying calyx puree and total soluble solids: sensory acceptance, quantitative descriptive and physicochemical analysis. Journal of Foodservice 17: 102-110. DOI: 10.1111/j.1745-4506.2006.00028.x.

Nakib, D.M.E., M.M. Ibrahim, N.S. Mahmoud, E.N.A.E. Rahman, and A.E. Ghaly. 2019. Incorporation of spirulina (Arthrospira platensis) in traditional Egyptian cookies as a source of natural bioactive molecules and functional ingredients: preparation and sensory evaluation of nutrition snack for school children. European Journal of Nutrition \& Food Safety 9: 372-397. DOI: 10.9734/ejnfs/2019/v9i430084.

Nalle, C.L., V. Ravindran, and G. Ravindran. 2011. Nutritional value of peas (Pisum sativum L.) for broilers: apparent metabolisable energy, apparent ileal amino acid digestibility and production performance. Animal Production Science 51: 150-155. DOI: 10.1071/AN10100.

Okereke, C.N., F.C. Iroka, and M.O. Chukwuma. 2015. Phytochemical analysis and medicinal uses of Hibiscus sabdariffa. International Journal of Herbal Medicine 2: 16-19.

Olagunju, A.I., O.S. Omoba, V.N. Enujiugha, and R.E. Aluko. 2018. Development of valueadded nutritious crackers with high antidiabetic properties from blends of acha (Digitaria exilis) and blanched pigeon pea (Cajanus cajan). Food Science and Nutrition 6: 1791-1802. DOI: 10.1002/fsn3. 748.

Oliver, G. and C.J. Brock. 1997. A rheological study of mechanical dough development and long fermentation processes for creamcracker dough production. Journal of the Science of Food and Agriculture 74: 294300. DOI: $\quad 10.1002 /($ SICI)10970010(199707)74:3<294::AID-

JSFA720>3.0.CO;2-B.

Owis, A.I. 2015. Broccoli; the green beauty: a review. Journal of Pharmaceutical Science and Research 7: 696-703.
Picauly, P. dan Tetelepta. 2016. Uji organoleptic crackers pisang tongka langit. Agritekno 5: 53-57.

Poutanen, K., L. Flander, and K. Katina. 2009. Sourdough and cereal fermentation in a nutritional perspective. Food Microbiology 26: 693-699. DOI: 10.1016/j.fm.2009. 07.011.

Rampersad, R., N. Badrie, and E. Comissiong. 2003. Physico-chemical and sensory characteristics of flavored snacks from extruded cassava/pigeonpea flour. Journal of Food Science 68: 363-367. DOI: 10.1111/j.1365-2621.2003.tb14166.x.

Rani, K.U., U.J.S.P. Rao, K. Leelavathi, and P.H. Rao. 2001. Distribution of enzymes in wheat flour mill. Streams, Journal of Cereal Science 34: 233-242. DOI: 10.1006/jcrs. 2000.0393.

Rezaei, M.N., V.B. Jayaram, K.J. Verstrepen, and C.M. Courtin. 2016. The impact of yeast fermentation on dough matrix properties. Journal of the Science of Food and Agriculture 96: 3741-3748. DOI: 10.1002/jsfa.7562.

Russo, M., I. Bonaccorsi, G. Torre, M. Saro, P. Dugo, and L. Mondello. 2014. Underestimated sources of flavonoids, limonoids and dietary fibre: availability in lemon's by-products. Journal of Functional Foods 9: 18-26. DOI: 10.1016/j.jff.2014. 04.004.

Sampaio, R.M., S.K. Marcos, I.C.F. Moraes, and V.H. Perez. 2009. Moisture adsorption behavior of biscuits formulated using wheat, oatmeal and passion fruit flour. Journal of Food Processing and Preservation 33: 105113. DOI: $10.1111 / \mathrm{j} .1745-4549.2008$. 00276.x.

Sandoval, A.J., L. Chaunier, H. Chiron, G.D. Valle, and A. Réguerre. 2017. Cellular structure and rheological properties of shaped fermented wheat flour dough. Journal of Cereal Science 73: 91-98. DOI: 10.1016/J.JCS.2016.12.001.

Sani, R. N., F.C. Nisa, R.D. Andriani, dan Maligan, J. M. 2014. Analisis rendeman dan skrining fitokimia mikroalga laut Tetraselmis chuii. Jurnal Pangan dan Agroindustri 2: 121-126.

Satija, A. and F.B. Hu. 2012. Cardiovascular benefits of dietary fiber. Current Atherosclerosis Reports 14: 505-514. DOI: 10.1007/s11883-012-0275-7. 
Schmidt, C., I. Geweke, S. Struck, S. Zahn, and H. Rohm. 2017. Blackcurrant pomace from juice processing as partial flour substitute in savoury crackers: dough characteristics and product properties. International Journal of Food Science and Technology 53: 237-245. DOI: 10.1111/ijfs.13639.

Seftiono, H., E. Djiuardi, and S. Pricilia. 2019. Analisis proksimat dan total serat pangan pada crackers fortifikasi tepung tempe dan kolesom (Talinum triangulare). Agritech 39: 160-168.

Shigechi, H., J. Koh, Y. Fujita, T. Matsumoto, Y. Bito, M. Ueda, E. Satoh, H. Fukuda, and Kondo, A. 2004. Direct production of ethanol from raw corn starch via fermentation by use of a novel surfaceengineered yeast strain codisplaying glucoamylase and $\alpha$-amylase. Applied and Environmental Microbiology 30: 5037-5040. DOI: 10.1128/AEM.70.8.5037-5040.2004.

Sinha, A.K., V.K. Kumar, H.P.S. Makkar, G.D. Boeck, and K. Becker. 2011. Non-starch polysaccharides and their role in fish nutrition-a review. Food Chemistry 127: 1409-1426. DOI: 10.1016/j.foodchem.2011. 02.042 .

Sirpatrawan, U. 2009. Shelf-life simulation of packaged rice crackers. Journal of Food Quality 32: 224-239. DOI: 10.1111/j.17454557.2009.00247.x.

Struck, S., D. Straube, S. Zahn, and H. Rohm. 2018. Interaction of wheat macromolecules and berry pomace in model dough: rheology and microstructure. Journal of Food Enginering 223: 109-115. DOI: 10.1016/j.jfoodeng.2017.12.011.

Surampudi, P., B. Enkhmaa, E. Anurad, and L. Berglund. 2016. Lipid lowering with soluble dietary fiber. Current Atherosclerosis Reports 18: 1-13. DOI: 10.1007/s11883016-0624-z.

Tarancón, P., S.M. Fiszman, A. Salvador and A. Tárrega. 2013. Formulating biscuits with healthier fats. Consumer profiling of textural and flavour sensations during consumption. Food Research International 53: 134-140. DOI: 10.1016/j.foodres.2013.03.053.

Tarazona-Díaz, M.P. and E. Aguayo. 2013. Assessment of by-products from fresh-cut products for reuse as bioactive compounds. Food Science and Technology International 19: 439-446. DOI: $10.1177 / 1082013212455346$.
Tarwendah, I.P. 2017. Jurnal review: studi komparasi atribut sensoris dan kesadaran merek produk pangan. Jurnal Pangan dan Agroindutri 5: 66-73.

Tezara, C., J.P. Siregar, H.Y. Lim, F.A. Fauzi, M.H. Yazdi, L.K. Moey, and J.W. Lim. 2016. Factors that affect the mechanical properties of kenaf fiber reinforced polymer: a review. Journal of Mechanical Engineering and Science 10: 2159-2175. DOI: 10.15282/jmes.10.2.2016.19.0203.

Thiele, C., S. Grassl, and M. Ganzle. 2004. Gluten hydrolysis and depolymerization during sourdough fermentation. Journal of Agricultural and Food Chemistry 52: 13071314. DOI: 10.1021/jf034470z.

Tutunchi, H., F. Naeini, A. Ostadrahimi, and M.J. Hosseinzadeh-Attar. 2020. Naringenin, a flavanone with antiviral and antiinflammatory effects: a promising treatment strategy against COVID-19. Phytotherapy Research 2020: 1-11. DOI: 10.1002/ptr. 6781.

Venkatachalam, K. and M. Nagarajan. 2017. Physicochemical and sensory properties of savory crackers incorporating green gram flour to partially or wholly replace wheat flour. Italian Journal of Food Science 29: 599-612. DOI: 10.14674/1120-1770IJFS808.

Xu, D., Y. Zhang, K. Tang, Y. Hu, X. Xu, and M.G. Gänzle. 2019. Effect of mixed cultures of yeast and lactobacilli on the quality of wheat sourdough bread. Frontiers of Microbiology 10: 1-13. DOI: 10.3389/fmicb. 2019.02113.

Yaseen, T., D.W. Sun, and J.H. Cheng. 2017. Raman imaging for food quality and safety evaluation: fundamentals and application. Trends in Food Science \& Technology 62: 177-189. DOI: 10.1016/j.tifs.2017.01.012.

Yazar, G., O.C. Duvarci, S. Tavman, and J.L. Kokini. 2017. LAOS behavior of the two main gluten fractions: gliadin and glutenin. Journal of Cereal Science 77: 201-210. DOI: 10.1016/j.jcs.2017.08.014.

Yildiz, E., G. Gungor, and D. Gocmen. 2019. Changes in bioaccessibility, phenolic content and antioxidant capacity of novel crackers with turmeric (Curcuma longa L.) and mahaleb (Prunus mahaleb L.) powders. Quality Assurance and Safety of Crops \& Foods 11: 107-116. DOI: 10.3920/QAS2018.1334. 
Yilmaz, E. and E. Karaman. 2017. Functional crackers: incorporation of the dietary fibers extracted from citrus seeds. Journal of Food Science and Technology 54: 3208-3217. DOI: $10.1007 / \mathrm{s} 13197-017-2763-9$.

Zheng, B., H. Zhao, Q. Zhou, J. Cai, X. Wang, W. Cao, T. Dai, and D. Jiang. 2020.
Relationships of protein composition, gluten structure, and dough rheological properties with short biscuits quality of soft wheat varieties. Agronomy Journal 112: 19211929. DOI: 10.1002/agj2.20127.

Copyright (C) 2021 Yovie F. Santoso, Fransiscus S. Pranata, Yuliana R. Swasti

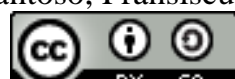

This work is licensed under a Creative Commons Attribution-ShareAlike 4.0 International License. 